\title{
On the Seedling Structure of Gymnosperms. IV.
}

\author{
BY \\ T. G. HILL, F.L.S., \\ Assistant Professor and Lecturer in Botany; University of London; University and \\ Goldsmiths' Colleges.
}

AND

E. DE FRAINE, F.L.S.

University of London; Goldsmiths' College.

With Plates XXII and XXIII, and three Figures in the Text.

GNETALES.

EPHEDRA.

THE germination of the seeds of Ephedra has been described by 1 Strasburger ${ }^{3}$ and Bower ${ }^{2}$; the latter author does not enter into the structure of the seedlings, but Strasburger draws attention to their morphology and the course of the cotyledonary and plumular bundles; he also describes briefly the transition to root-structure, and remarks upon the close resemblance, in the transition phenomena, between Ephedra and Araucaria. Passing on to our own observations, the seedlings of the species of this genus examined, E. distachya, E. fragilis, E. campylopodia, and $E$. altissima, are indistinguishable one from the other, and are dicotyledonous, epigeal, and linear in shape (P1. XXIII, Figs. 6, 7, and 8). At first the cotyledons are short, but ultimately they grow to a much greater length; thus seed-leaves ten centimetres long are not uncommon in $E$. fragilis. On the other hand the hypocotyl does not elongate to a corresponding degree, and it is very slender.

The structure of the seed-leaves is very simple and calls for but little comment. The epidermis is covered with a cuticle which is very thin over the ordinary epidermal cells, but over the stomates, which are sunken below the general surface level of the leaf, it is considerably thicker.

${ }^{1}$ Strasburger: Die Coniferen und die Gnetaceen (Jena, 1872).

2 Bower: The Germination and Embryology of Gnetum Gnemon (Q.J.M.S., xx, 1882).

[Annals of Botany, Vol. XXIV. No. XCIV, April, 1910.] 
The mesophyll is homogeneous and consists of normal parenchymatous cells; the intercellular space system is not highly developed.

Each cotyledon contains two vascular bundles which are collateral in structure and do not exhibit any vascular rearrangement within the seed-leaves. Transfusion tracheides, so far as has been seen, are absent, and no fibrous elements, abutting directly on to the soft bast, such as occur in so many species of Pinus, \&c., have been observed (Pl. XXII, Fig. I). $E$. altissima, however, does possess a number of fibrous elements, with thickened, but apparently unlignified walls, scattered throughout the mesophyll of the seed-leaves and in the cortical ground-tissue of the hypocotyl.

The orientation of the bundles of a cotyledon is peculiar; they are arranged in such a manner that the plane of the bundles is at right angles, or nearly so, to the dorso-ventral plane of the leaf; the protoxylem of one bundle thus is directed towards the same tissue of the strand on the other side (Diagram I, Fig. I).

In all cases a well-marked cotyledonary tube is formed (Diagram I, Fig. 2).

\section{Transition.}

E. distachya. The orientation of the bundles of the cotyledons just remarked upon obtains throughout the whole length of the seed-leaves, and in this condition they enter the hypocotyledonary axis; thus there are four bundles in the hypocotyl arranged in two well-defined pairs (Diagram I, Fig. 3). During the downward passage the two strands from each cotyledon approach one another and, concurrently, a rearrangement of the elements of the wood takes place, which leads finally to the fusion of the protoxylem elements (Diagram I, Fig. 4). The approachment continues so that the xylem-masses of the bundles of each pair come into continuity, with their protoxylems in an exarch position (Diagram I, Fig. 5). The four groups of phloem elements still retain their identity, and continue so to do through the greater length of the root of young seedlings (Diagram I, Fig. 6); indeed, we have seen no absolutely certain case in which the phloem, which, in this genus, generally is very poorly defined when viewed in transverse section, forms two well-marked strands as would be expected. This fact is curious, and may be compared with the similar state of affairs which occurs in certain Cactaceae. ${ }^{1}$

The transition-phenomena in $E$. campylopodia, E. fragilis, and $E$. altissima are precisely similar to those obtaining in $E$. distachya.

Attention may now be drawn to a rather interesting feature occurring in the hypocotyl of all the seedlings of the species of Ephedra examined.

At a level just below the cotyledonary node a shallow band of interfascicular cambium occurs which joins the fascicular cambium of the opposing bundles of each cotyledonary pair (Diagram I, Fig. 3). This

1 See de Fraine, On the seedling structure of Cactaceae (Ann. Bot., xxiv, Jan., I9IO). 
meristem is bounded on its inner side by a number of short tracheides having an appearance which strongly recalls that usually associated with
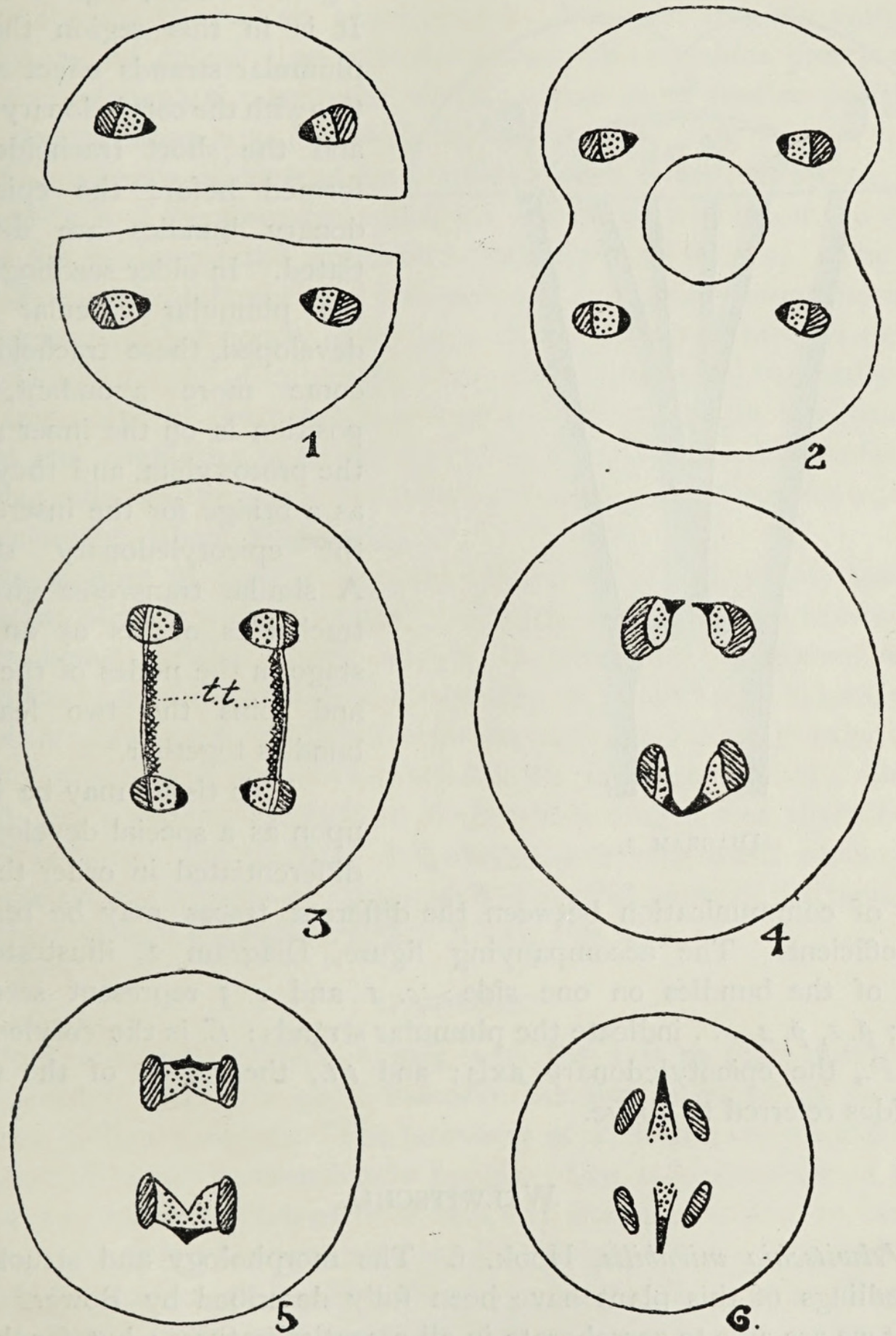

DiAgram I. Ephedra.-In this and the following text-figures, the protoxylem is represented by black areas, the metaxylem by dots, the phloem by diagonal shading, and the transfusion elements by cross hatching.

many transfusion tracheides of the cotyledons of other Gymnosperms. These elements, in Ephedra, form a bridge connecting the xylem-masses of the two corresponding bundles. 
The cambium does not form, as far as has been seen, any phloem, so that the appearance is not altogether that of normal secondary thicken-

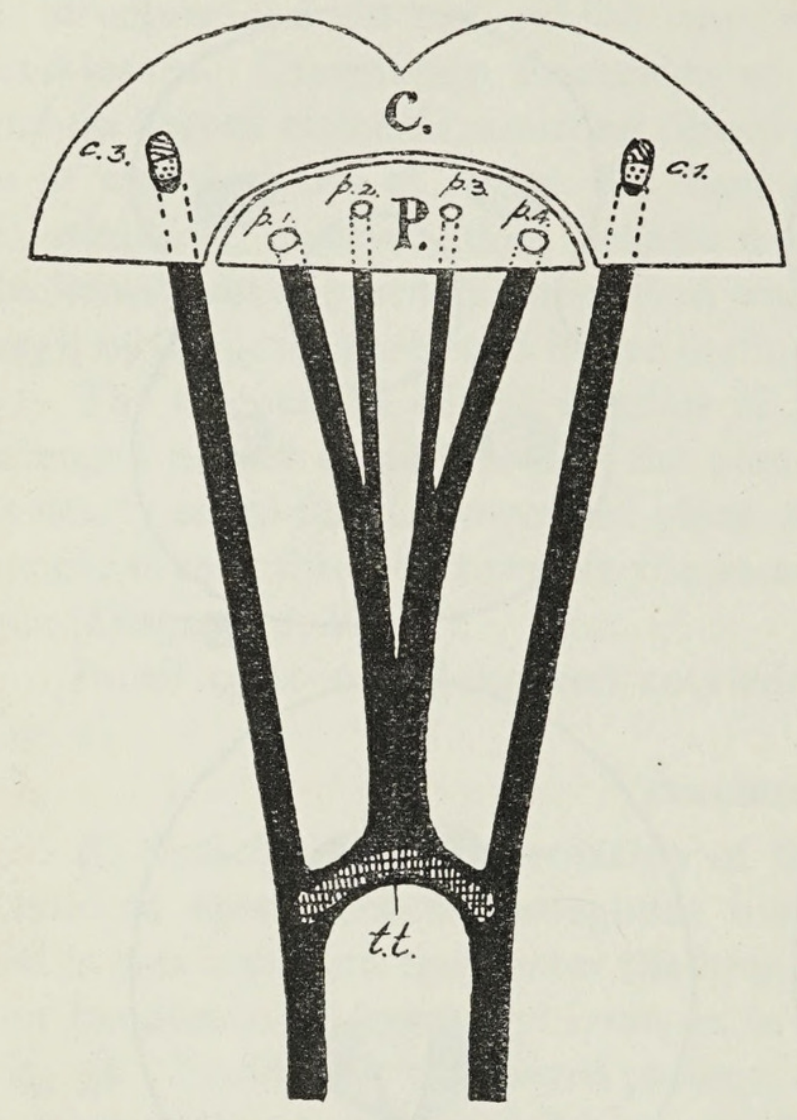

DIAGRAM 2. ing (P1. XXII, Figs. 2 and 3). It is in this region that the plumular strands effect a junction with the cotyledonary traces, and the short tracheides are formed before the epicotyledonary bundles are differentiated. In older seedlings, with the plumular vascular tissue developed, these tracheides become more abundant, their position is on the inner side of the protoxylem, and they serve as a bridge for the insertion of the epicotyledonary strands. A similar transverse girdle of tracheides occurs at an early stage in the nodes of the shoot and joins the two leaf-trace bundles together. ${ }^{1}$

This tissue may be looked upon as a special development, differentiated in order that the means of communication between the different traces may be rendered more efficient. The accompanying figure, Diagram 2, illustrates the course of the bundles on one side: $c . I$ and $c .3$ represent seed-leaftraces; $p .1, p .2, \ldots$ indicate the plumular strands; $C$. is the cotyledonary tube; $P$. , the epicotyledonary axis; and t.t., the region of the special tracheides referred to above.

\section{WELWITSCHIA.}

Welwitschia mirabilis, Hook. f. The morphology and structure of the seedlings of this plant have been fully described by Bower, ${ }^{2}$ whose account we are able to corroborate in all essential features; but, for the sake of completeness, it is desirable to draw attention to the more important facts bearing directly on the present work.

The seedling is illustrated in Plate XXIII, Figs. 9, IO, and II, from which it may be seen that the epigeal cotyledons are two in number and relatively

1 Strasburger, loc. cit.

${ }^{2}$ Bower: On the Germination and Histology of Welwitschia mirabilis (Q.J.M.S., xxi, I88I). 
large; just above the cotyledonary node they fuse together to form a tube. The lower end of the hypocotyl bears on one side a spade-like projection, the foot or sucker, which remains embedded within the endosperm, from which it absorbs the stored nourishment. The foot consists entirely of parenchyma, and contains no vascular tissue; it resembles pretty closely the hypocotyledonary outgrowth which occurs in a similar position in certain Angiosperms, e. g. Mirabilis multiflora.

The epidermis is covered by a cuticle which is very thin except over the guard-cells of the stomates, which are sunken slightly below the general level of the epidermis and occur on both surfaces of the leaf. The mesophyll is but feebly differentiated into palisade and spongy parenchyma, and the air spaces are but poorly developed. Some of the mesophyll elements are practically devoid of contents; these cells occur more especially along the lateral edges of the cotyledons and around the larger bundles. Our material was insufficient to enable us to examine older cotyledons for these particular cells; in the young seed-leaves they appear rather like immature fibrous elements (Plate XXII, Fig. 4, a).

The number of bundles in each cotyledon varies; usually there are four larger strands with a number of much smaller traces between, the venation being parallel. The smaller bundles freely anastomose, and towards the base of the seed-leaves, they fuse on to the larger traces, so that four bundles from each cotyledon enter the hypocotyledonary axis.

The structure of these vascular strands is quite normal; they are endarch and collateral throughout their whole length, and there is some cambial activity; the tracheae frequently have very thick walls, and in transverse section present an appearance much like some of the metaxylem elements of certain Cactaceae (Plate XXII, Fig. 4).

\section{Transition.}

From each seed-leaf four strands enter the axis so that, at the top of the hypocotyl, there are eight vascular bundles arranged in four pairs (Diagram 3, Figs. I and 2). The members of each pair very quickly fuse together, and rotation immediately begins. The xylem-masses of each of the now two bundles, derived from one and the same cotyledon, face each other in a manner which strongly recalls the appearance presented by the corresponding structures in Ephedra (Diagram I, Fig. 2, and Diagram 3, Fig. 3). Each strand now gradually rotates outwards, a movement which ultimately brings the four protoxylem groups into the exarch position. At the same time the protoxylems tend to become diffuse, and new protoxylem elements may make their appearance in the ground tissue; these, at first, are not in continuity with the same tissue derived from the cotyledons (Plate XXII, Fig. 5). At about this level the cambium is very conspicuous, and extends in such a manner as partly to enclose the phloem. 
The appearance of the bundle throughout the greater length of the hypocotyl is represented in Diagram 3, Fig. 5. The foot, which is situated in the cotyledonary plane, although relatively large, has no vascular supply;

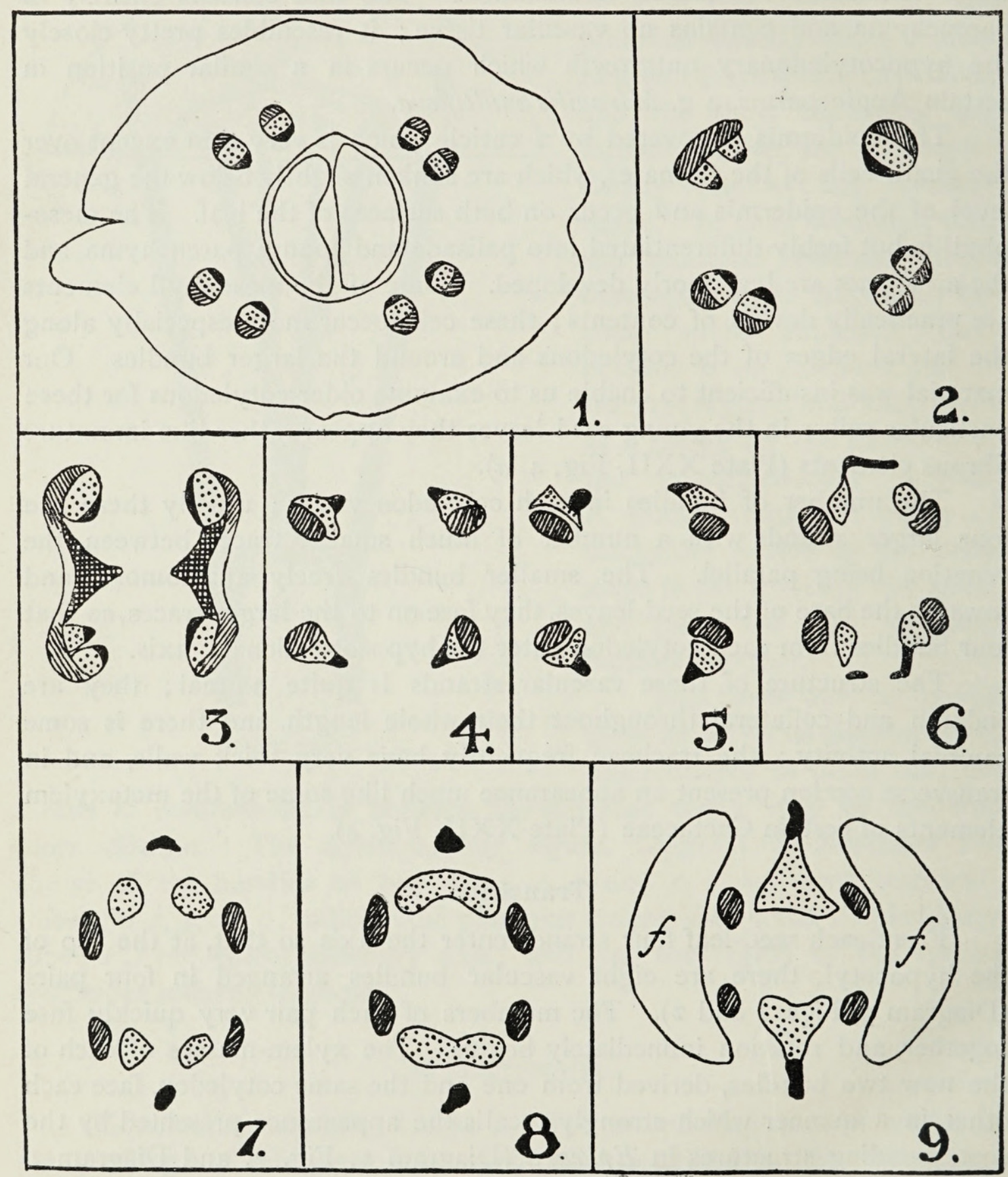

Diagram 3. Welivitschia.

but the two bundles on that side of the axis gradually curve outwards towards it, and, when immediately opposite, increase in size. This increase is especially noticeable in the xylem, which, in area, is about twice as extensive as the same tissue of the bundles distal to the foot, but at the same level. 
Below the sucker the transition to root-structure rapidly proceeds; the four bundles undergo a centripetal displacement; at the same time, the individuals of each pair of strands come more closely together, and, at a slightly lower level, the corresponding groups of protoxylem elements effect a junction. Thus there are four masses of phloem, four of metaxylem, and two collections of protoxylem elements (Diagram 3, Figs. 7 and 8).

While these changes are being effected two broad bands of thickwalled fibrous tissue are differentiated on the outer sides of the phloem elements ( $f$. Diagram 3, Fig. 9).

At first the two isolated groups of protoxylem elements are tangentially elongated, but a rearrangement soon takes place, resulting in the formation of two rounded masses (Diagram 3, Fig. 8). Then the corresponding metaxylems fuse, and, at a lower level, the metaxylems and protoxylems effect a junction (Diagram 3, Figs. 8 and 9). The four groups of phloem elements retain their identity for some considerable distance downwards, as in the case of Ephedra described above. Fusion does take place ultimately, we believe, although it is difficult to say with absolute certainty because the soft-bast in the root is very poorly differentiated; indeed, in transverse section it is hardly distinguishable.

The endodermis is first visible at a level just below the region of the foot, appearing at the same time with the fibrous tissue already alluded to. At lower levels the endodermis may be two or three cells in thickness.

The occurrence of a band of a form of transfusion tracheides in the hypocotyl of Ephedra has already been described above. Welwitschia also shows them, and in this plant they are very prominent and have a disposition exactly the same as in Ephedra, although in the former plant they also show an extension into the central ground-tissue (Diagram 3, Fig. 3). Abutting on to the margin of these two bridges are a number of cambiform cells, and possibly also some phloem elements, but no sieve-tubes have been observed. The presence of these tracheides is not due in the first place to the presence of a cambium, but rather to the differentiation of the groundtissue elements. A cambium, however, may soon put in an appearance, and thus lead to their increase. The material at our disposal was too young to show differentiated epicotyledonary strands, but it is clear from Bower's account and illustrations, taken in conjunction with our own observations, that there is a wonderfully close agreement between Ephedra and Welwitschia in the inter-relationships between the plumular and cotyledonary bundles and these transfusion tracheides.

It may be remarked in this particular connexion that Bower's account and ours appear to differ: this is due to the fact that Bower's seedlings were older, with the plumular traces developed; and as these mask the presence of the transfusion tracheides, it would be impossible to realize their nature and significance without younger stages. 


\section{GNetum.}

The seedlings of Gnetum Gnemon have already been considered by Bower, ${ }^{1}$ and as our results are in general agreement with his, it is necessary for us only to draw attention to the main features connected with the transition-phenomena. Unlike Welwitschia, the seeds of which germinate in about two weeks, the seedlings of Gnetum do not appear above ground much before three months, at the earliest, after sowing; the majority take eight months to a year.

The general morphology of the seedlings of Gnetum Gnemon, Linn., have already been described and illustrated, ${ }^{2}$ but for the sake of completeness the figures referred to are reproduced here. Plate XXIII, Fig. I2, shows the split seed-coat and a very short primary root; the hypocotyl is seen to be curved with its tip still embedded within the prothallus. The hypocotyl soon straightens and is withdrawn from the prothallus, but the seed-leaves are still quite small and scale-like, which condition they retain for some time: this stage is illustrated in Plate XXIII, Fig. ${ }^{3} 3$, in which example the prothallus has been partly cut away in order to show the sucker or foot embedded within it. The next figure is that of an older seedling, and shows the rod-like foot entirely freed from the tissues of reserve; it will be observed that the cotyledons have increased in size, and that a few lateral roots have arisen, but the main root still remains stunted, a feature figured by Roxburgh as occurring in Gnetum scandens."

After a time the primary root elongates considerably and the seedleaves increase greatly in size (Plate XXIII, Figs. 15 and I6), and ultimately resemble the foliage leaves very closely; but for some time they are, in $G$. Gnemon, unequal in size, a feature which also obtains in $G$. scandens.

The seedling of Gnetum scandens, Roxb., judging from one example, very closely resembles $G$. Gnemon; on the other hand, that of $G$. moluccense, Karst., the seed of which is much larger than that of either $G$. scandens or G. Gnemon, shows some points of difference. One only of several seeds of $G$. moluccense germinated, and this example, owing to the fact that it was planted the wrong way or possibly was disturbed and replaced improperly, showed the root and shoot much curved. A lateral view of this seedling is illustrated in Plate XXIII, Fig. I 8 ; the chief points of interest are the small size of the seed-leaves, the early development of a cotyledonary bud, and the relatively advanced state of the epicotyl, although the foliage leaves are still rudimentary. Fig. 20 is an end-on view of the same seedling, in which $f$ indicates the region of insertion of the sucker, and, finally, Fig. I 9 illustrates a dissection which shows the sucker.

1 Bower: The Germination and Embryology of Gnetum Gnemon (Q.J.M.S., xx, 1882). 1908).

${ }^{2}$ Hill, T. G.: The Germination of Gnetum Gnemon (Journ. Roy. Hort. Soc., xxxiv, Pt. I, 
Inasmuch as Bower has described the structure of the foot and has considered its morphology very fully, there is no need for us further to deal with it in detail; it, however, may be remarked that we look upon this structure as an outgrowth produced expressly to effect the removal of the reserve food materials, and that it has no phylogenetic importance.

A short cotyledonary tube occurred in all examples of the species examined.

With regard to the structure of the seed-leaves there is nothing of importance to remark upon. The young cotyledons have very little lamina and a well-marked midrib containing five vascular bundles, which in their structure resemble those of Welwitschia. The strands are endarch and collateral throughout the length of the cotyledon, and at the base they tend to fuse together, so that in G. scandens and G. moluccense, as far as has been seen, and in some examples of G. Gnemon, five strands may enter the axis from one cotyledon, and four from the other; in other seedlings of Gnetum Gnemon five bundles enter the hypocotyl from each seed-leaf. Within the axis the bundles tend to fuse together, the extreme lateral strands of one cotyledon joining with the corresponding bundles of the other seed-leaf, but this again is not constant in all cases.

\section{Transition.}

At a level just below the cotyledonary node the bundles anastomose freely, and some, at any rate, of the xylem elements of these connexions are differentiated from the ground-tissue, and resemble the transfusion tracheides remarked upon above as occurring in the hypocotyl of Ephedra and Welwitschia. In the case of G. moluccense, the anastomoses between the bundles of the cotyledons, the cotyledonary bud, and the plumule were of the greatest complexity, and the special tracheides were extensively developed. After these general connexions between the various traces have been made, six large bundles obtain in the upper part of the axis together with a few small intervening ones, ill developed and small at this level, but rapidly increasing in size and differentiation lower down; also the larger strands branch and new ones may come into being between the preexisting traces. Thus the number of bundles is increased, and throughout the greater length of the hypocotyl a varying number, about twelve to fifteen, occur in the species examined.

In that part of the axis situated immediately above the foot, a reduction in the number of bundles is brought about by the union of neighbouring structures; several of those on the foot side of the axis enter the upper part of the sucker, and so supply it with vascular tissue as described by Bower. After having passed to the extremity of the foot these strands return along the lower side, and thus regain the axis. Of these bundles, the two last, on their arrival near the central region of the hypocotyl, are seen 
to be in a state of transition, their protoxylems being directed towards each other and outwards. The completion of this rearrangement forms one pole of the primary root. The bundles on the other side of the axis continue their course straight downwards; the protoxylem of the two strands situated in the cotyledonary plane, at the upper level of, or immediately above, the sucker, turn towards each other and outwards, and thus form the second pole of the root-structure, which is organized before that on the foot-side of the axis.

In seedlings of the stage illustrated in Pl. XXIII, Fig. I4, isolated protoxylem elements may be found at some distance above the foot, at which higher levels they are few in number and separated one from the other; but lower down they increase in number, and ultimately become attached to that protoxylem pole of the root situated on the side of the axis opposite the foot. These isolated elements have not been observed in the corresponding position on the sucker side of the axis. This peculiarity, in all probability, is due to the elongation of the axis after the rearrangements of the vascular tissues have been accomplished.

The remaining changes take place on normal lines; the phloemmasses of the strands directly concerned in the transition pass to one side and join with the bast of the bundles situated in the intercotyledonary plane, which close up and so produce a proper root-structure which, in the species examined, G. scandens, G. Gnemon, and G. moluccense, is diarch.

Attention may now be drawn to a few minor points in the structure of the hypocotyl. In seedlings of about the stage indicated in P1. XXIII, Fig. I4, a lignification of the elements of the central ground-tissue occurs in the lower regions of the axis; this alteration takes place centripetally, but immediately above the foot the thickening is not nearly so extensive as at higher levels. In the same parts of the axis, and at about the same time, an interfascicular cambium arises and also a phellogen which is epidermal in origin. The periderm formation below the sucker, i.e. in the root region, is internal.

It is clear that the transition-phenomena in the seedlings of Ephedra, Welwitschia, and Gnetum are essentially the same; each pole of the diarch root-structure being formed by the rearrangement of the vascular tissue of two seed-leaf-traces. In the case of Gnetum this similarity is obscured by the larger number of cotyledonary bundles and by the numerical increase of these in the hypocotyledonary axis. In all cases the transition to root-structure occurs at the lower end of the hypocotyl. On the other hand, there are some differences, the chief of which are in the number of vascular bundles in the cotyledons. In Ephedra each seed-leaf has two strands which retain their identity until the transition is accomplished; in Welwitschia the number of traces in the blade of each cotyledon is eight or more, but just before entry into the axis, these fuse together; thus 
four are produced and are arranged in two pairs, the units of each of which join together in the hypocotyl, so that, from this level downwards, the appearance is remarkably like that of Ephedra; finally, in Gnetum, the bundles are very numerous in the blade of each seed-leaf; the petiole, however, contains five which, by fusion, may be reduced further, so that either four or five bundles enter the axis.

Comparing the Gnetales with other Gymnosperms, it is seen that the transition-phenomena exhibited by these plants resemble those of the Podocarpeae ${ }^{1}$ and the Araucarieae, ${ }^{2}$ the similarity between which two groups has already been remarked upon. Ephedra is practically identical with Podocarpus, the only difference being that in the former plant the transition is slower, taking place in the lower region of the hypocotyl. The same observations apply equally well to Welwitschia, although the resemblance is masked by the larger number of cotyledonary traces; still more so is this the case in Gnetum.

A comparison with the Araucarieae shows, with regard to the features under discussion, that Welwitschia is very like indeed to Araucaria Cunninghamii. The resemblance between Ephedra and Gnetum on the one hand, and the Araucarias on the other, is, on a superficial examination, less well marked owing to the fewer number of seed-leaf-traces in Ephedra, and to the numerical increase and anastomoses, within the hypocotyl, of these structures in Gnetum. The comparison of the critical stages, however, reveals the similarity between these plants. There is also a resemblance between Welzeitschia and Ginkgo, and Gnetum and certain Cycads, as regards the number of bundles in the cotyledons, but the behaviour of these strands in the transition region is, however, not the same.

The present paper concludes the statement of our observations on the seedling structure of the Gymnosperms, and incomplete though it be, it would have been impossible to have considered the subject even thus fully without the co-operation of many in supplying us with material.

To the following we wish to render thanks and to express our appreciation of their kindness :-

The Directors of the Botanic Gardens of Brisbane, Buitenzorg, Kew, Peradeniya, and Sydney; Mr. Boodle, Mr. de Fraine, Prof. H. H. W. Pearson, Dr. D. H. Scott, Mr. Tansley, and Miss Thomas.

More especially are we indebted to Mr. Hales, the Curator of the Old Physic Garden, Chelsea; and him we desire particularly to thank, not only for material, but also for the trouble and care he has taken in the germination of our seeds.

Our general conclusions will appear later on, when our work on certain Angiosperms is completed.

A correction.-In Part III, p. 434, it is stated that Sprecher does not

1 Part I (Annals, xxii, rgo8).

${ }^{2}$ Part II (Annals, xxiii, I909). 
remark upon the presence of four vascular bundles in the apex of the cotyledons of Ginkgo. The author cited does comment upon this feature, and in making this correction we desire to express our regret to Dr. Sprecher for the misrepresentation.

\section{SUMMARY.}

\section{Cotyledons.}

I. The plants examined, viz. Ephedra distachya, E. fragilis, E.campylopodia, E. altissima, Welwitschia mirabilis, Gnetum Gnemon, G. scandens, and $G$. moluccense, have dicotyledonous and epigeal seedlings.

2. The cotyledons of Ephedra are linear in shape; at first they are small, but with increasing age they elongate greatly. The seed-leaves of Welwitschia are large and leaf-like, and persist relatively for a long time; those of Gnetum to begin with are scale-like and their growth is slow, finally they attain a large size, and closely resemble the foliage leaves.

3. In all cases a short cotyledonary tube is formed.

4. The number of cotyledonary bundles varies; in all the Ephedras examined there are two traces in each seed-leaf; in Welwitschia there are in the base of each seed-leaf four strands arranged in two pairs ; in Gnetum four or five bundles occur in the lowest region of the cotyledons.

5. The seed-leaf-traces are endarch and collateral in structure.

\section{HypocotyL.}

6. The upper part of the hypocotyledonary axis shows a stem-like structure; the chief bundles, in the material examined, are those derived from the cotyledons; of these strands there are four in Ephedra, eight or less in Welwitschia which quickly become reduced to four, and a variable number, about twelve or fifteen, occur throughout the greater length of the hypocotyl in Gnetum.

7. In Gnetum and Welwitschia a parenchymatous outgrowth occurs at the base of the hypocotyl; this is the foot or sucker, which is rod-like in the former plant and spade-like in Welwitschia. The foot functions as an organ of absorption, and remains embedded in the prothallus. The sucker in Welwitschia has no vascular supply, but in Gnetum the bundles in the foot are numerous and well differentiated.

A foot has not been observed in Ephedra.

This structure is not considered to have any phylogenetic importance.

8. Short tracheides, closely resembling the transfusion tracheides obtaining in the cotyledons of other Gymnosperms, occur in all the plants examined in the region of the insertion of the plumular bundles on to the cotyledonary traces. These tracheides form a bridge between the corresponding bundles of the seed-leaves. 


\title{
Transition.
}

9. The transition to root-structure takes place in the lower region of the hypocotyl; in Welwitschia and Gnetum at the level of and immediately below the foot.

I0. Each pole of the root-structure is formed from two cotyledonary bundles which rotate towards each other and outwards, and so bring their protoxylems into an exarch position. These groups of elements become more compact, and the corresponding metaxylem-masses come into continuity. The groups of phloem elements pass towards the intercotyledonary plane, but their fusion may be delayed considerably.

II. In all cases the primary root is diarch.

I2. In Gnetum the primary root remains short and peg-like for some time; later, it elongates after two or three lateral roots have been formed. In Ephedra and Welwitschia there is no delay in the growth of the primary root.

\section{EXPLANATION OF FIGURES IN PLATES XXII AND XXIII.}

\author{
Illustrating Mr. T. G. Hill's and Miss de Fraine's paper on the Seedling \\ Structure of Gymnosperms.
}

Abbreviations used:- $f$., region of insertion of foot: L.S., longitudinal section: $m x$., metaxylem : ph., phloem : px., protoxylem: s., foot; T.S. transverse section.

\section{PLATE XXII.}

Figs. I-5 $\times 240$.

Fig. I. Ephedra distachic. T.S. of part of cotyledon.

Fig. 2. E. fragilis. T.S. hypocotyl, showing the transfusion tracheides.

Fig. 3. E. fragilis. The same in L.S.

Fig. 4. Welwitschia mirabilis. T.S. of part of cotyledon.

Fig. 5. W. mirabilis. T.S. hypocotyl, showing a vascular bundle and isolated protoxylem elements.

\section{PLATE XXIII.}

Figs. 6-20 natural size.

Fig. 6. Ephedra distachia. Young seedling.

Fig. 7. E. fragilis. Older seedling.

Fig. 8. E. campylopodia. Still older seedling, showing the much elongated seed-leaves and the plumule.

Fig. 9. Welwitschia mirabilis. Seedling.

Fig. 10. The same with seed-coat removed.

Fig. II. The same with the prothallus removed in order to show the spade-like foot.

Figs. 12-17. Different stages in the growth of the seedlings of Gnetum Gnemon.

Fig. 12. Very young seedling, showing short primary root and the curved hypocotyl, the tip of which is still enclosed within the prothallus. 
Fig. I3. An older example, partly dissected to show the foot embedded within the prothallus; the cotyledons are still very small.

Fig. 14. An older specimen from which the prothallus has been entirely removed to show the rod-like foot (s.). The seed-leaves, although relatively larger, are still small, and the primary root is still stunted and bears three lateral roots.

Fig. I 5. In this seedling the root has elongated and the cotyledons have increased in size.

Fig. I6. An older seedling, showing the seed-leaves much further developed. Their difference in shape and size may be noted.

Fig. I 7 . The top part of a young plant, showing the first pair of foliage leaves and, below them, the seed-leaves, which are partly represented in outline.

Fig. 18. G. moluccense. Seedling, showing the split seed-coat, the scale-like cotyledons, and the epicotyledonary axis.

Fig. 19. G. moluccense. A dissection to show the sucker.

Fig. 20. G. moluccense. An end-on view of the seedling represented in Fig. 18. f. indicates the insertion of the sucker.

\section{INDEX.}

PART I. Taxaceae, Podocarpeae, Cupressineae, and Abietineae, vol. xxii, p. 689.

PART II. Abietineae (concluded) and Araucarieae, vol. xxiii, p. 189.

PART III. Ginkgoaceae and Cycadaceae, vol. xxiii, p. 433.

PART IV. Gnetales, vol. xxiv, p. 3 I9.

$\left(^{*}\right)$ Indicates an illustration.

Abietineae (*), I, p. 706; II, p. 189.

Abies amabilis, II, pp. 19I, I95.

A. balsamea, II, pp. I9I, I93.

A. firma, II, p. I94.

A. magnifica var. Shastensis, II, pp. I9I, I 95.

A. pectinata $(*)$, II, pp. 19I, 194.

A. sachaliensis, II, p. I94.

A. sibirica $(*)$, II, p. I9I.

A. Veitchii, II, pp. 191, 193.

Actinostrobus pyramidalis (*), I, p. 703.

Araucarieae (*), II, p. 2 I 2.

Araucaria brasiliensis $(*), \mathrm{II}$, p. 216.

A. Cunninghamii $\left.{ }^{*}\right)$, II, p. 2 I 2.

Bowenia, III, p. 454.

Callitris calcarata, I, p. 704.

C. Muelleri, I, p. 704 .

C. rhomboidea, I, p. 706 .

C. robusta, I, p. 704

Cedrus atlantica, II, pp. 197, 198 .

C. Deodara, II, pp. $197,198$.

Cephalotaxus drupacea, I, p. 692.

C. Fortunei, I, p. 692 .

C. pedunculata $(*)$, I, p. 690 .

Ceratozamia, III, p. 452 .

Cryptomeria japonica, I, p. 708.
Cupressineae (*), I, p. 696 .

Cupressus Lawsoniana, I, p. 699.

C. macrocarpa, I, p. 702 .

C. obtusa, I, p. 699.

C. pisifera, I, p. 699.

C. torulosa $(*)$, I, p. 699.

Cycadaceae (*), III, p. 437 .

Cycas, III, p. $45 \mathrm{I}$.

Dioon edule (*), III, p. 446.

Encephalartos Altensteinii (*), III, p. 449.

Ephedra altissima, IV, pp. 319, 320.

E. campylopodia (*), IV, pp. 319, 320.

E. distachya $\left(^{*}\right)$, IV, p. 320 .

E. fragilis $(*)$, IV, pp. 319, 320 .

Ginkgo biloba (*), III, p. 433.

Gnetales (*), IV, p. 3 I 9 .

Gnetum Gnemon (*), IV, p. 326.

G. moluccense (*), IV, p. $3^{26}$.

G. scandens, IV, p. 326 .

Juniperus bermudiana, I, p. 698 .

J. Cedrus (*), I, p. 698.

J. procera, I, p. 698.

I. virginiana (*), I, p. 696 .

Larix europaea (*), II, p. 2 I0.

L. leptolepis, II, p. 2 Iо. 


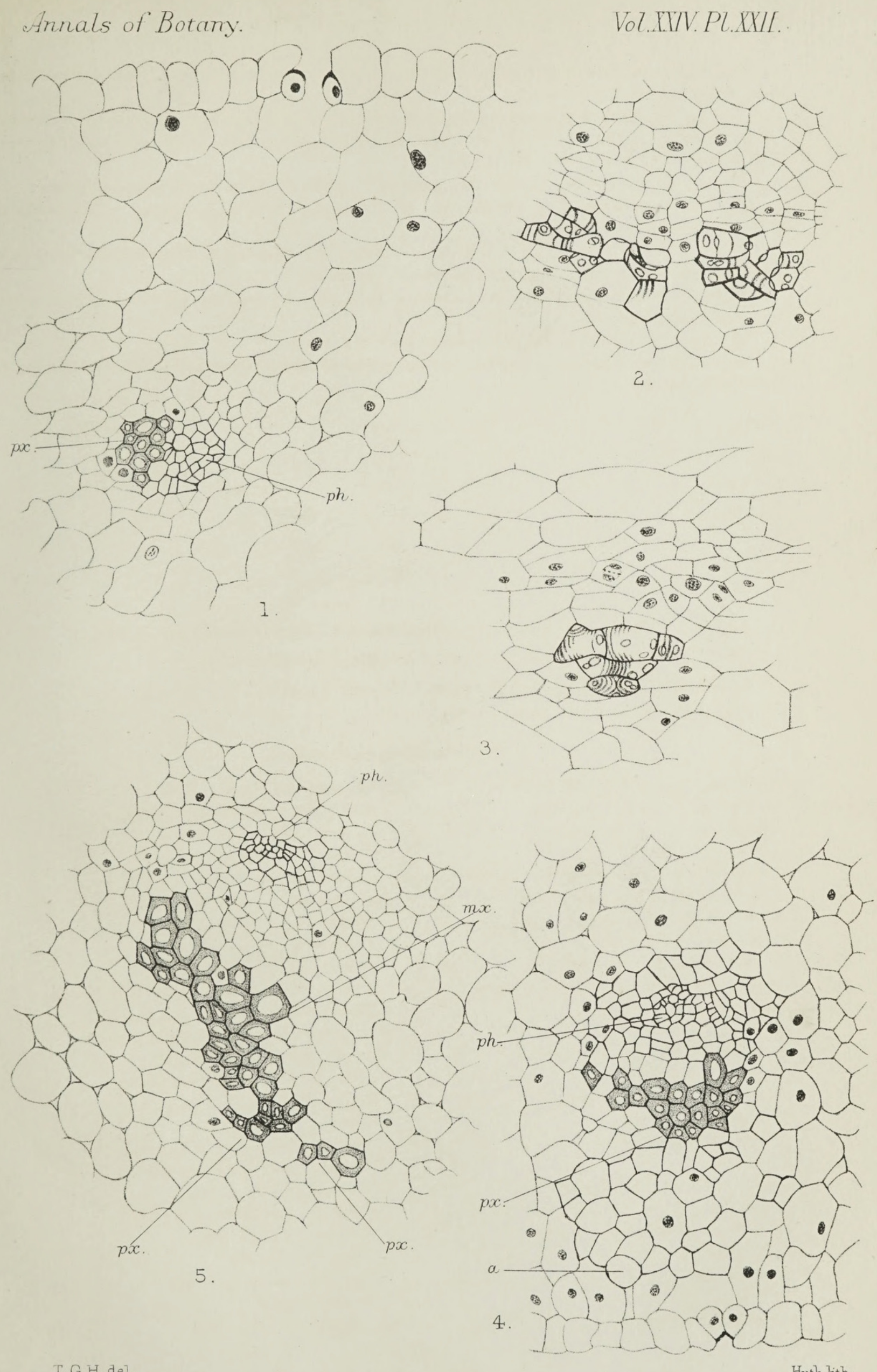

T. G.H.del. $\quad$ Huth.lith.

HILL \& DE FRAINE - SEEDLING STRUCTURE OF GYMNOSPERMS 


Annals of Botany.
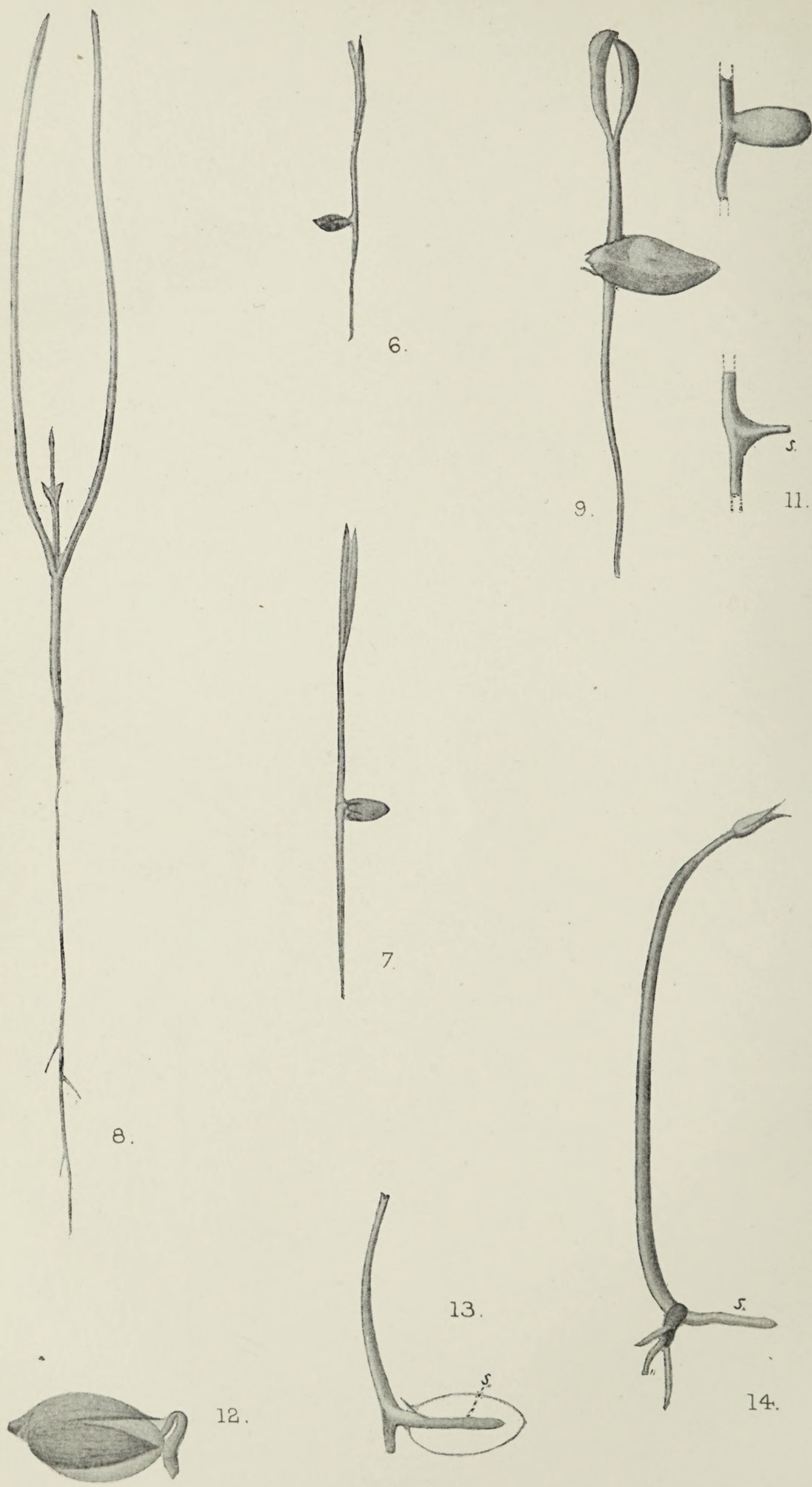

10.
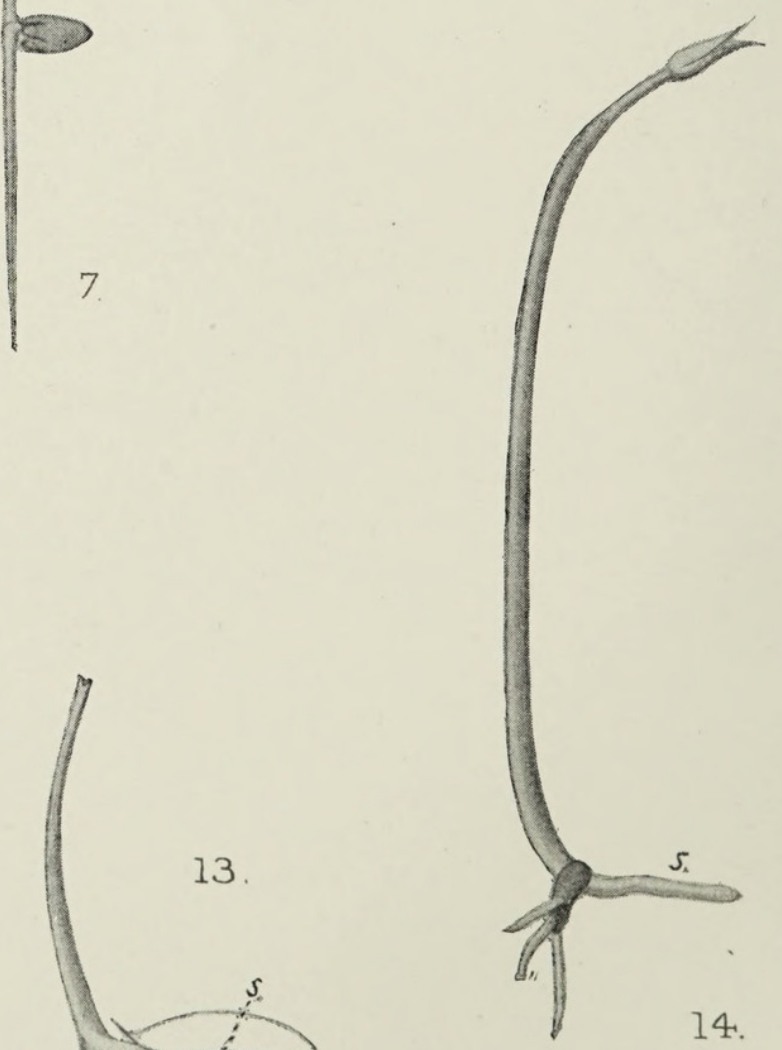

12.

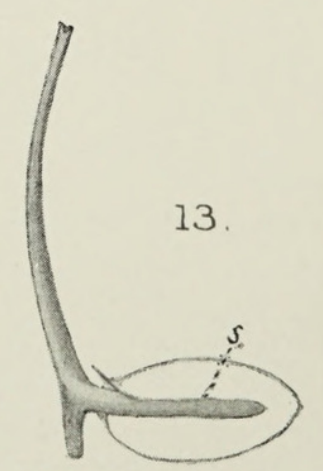

14.

T.G.H. del ad.nat.

HILL \& DE FRAINE - SEEDLING STRUCTURE OF GYMNOSPERMS. 


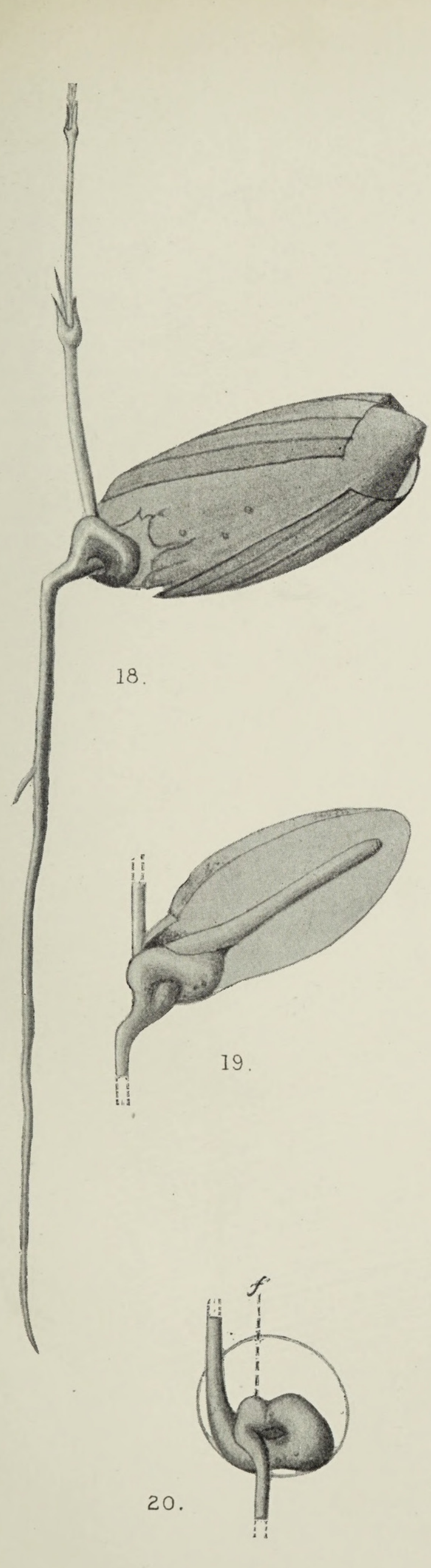

\section{Vol.XXIV.PL.XXIII.}
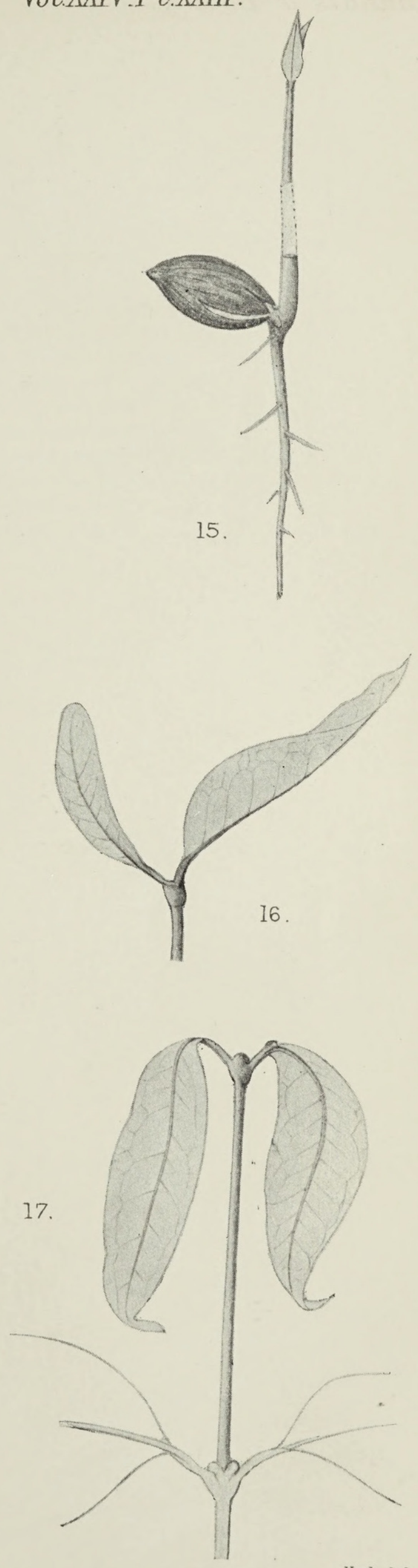

Huth lith. 



\section{Seedling Structure of Gymnosperms. IV.}

L. occidentalis, II, p. 2 IO.

Libocedrus decurrens (*), I, p. 702.

Macrozamia spiralis (*), III, p. 438 .

Microcycas, III, p. 453 .

Picea ajanensis (*), II, pp. 195, 196.

P. Morinda, II, pp. 195, 197 .

P. nigra, II, pp. I95, 197 .

Pinus australis (*), II, pp. I99, 202.

$P$. canariensis, II, pp. I99, $20 \mathrm{I}$.

P. contorta, II, pp. I99, 203.

P. contorta var. Murrayana (*), II, pp. I99, 206.

$P$. Coulteri, II, pp. 199, 201.

$P$. Gerardiana, II, pp. 199, 200.

$P$. halepensis, II, pp. 199, $20 \mathrm{I}$.

$P$. insignis, II, pp. 199, 203.

P. montana var. gallica (*), II, pp. I99, 206.

P. Pinea, II, p. I99.

$P$. sylvestris (*), II, pp. 199, 207.

P. Thunbergii, II, pp. 199, 200.

Podocarpeae (*), I, p. 694 .
Podocarpus chinensis (*), I, p. 694 .

Pseudolarix Kaempferi, II, p. 212.

Sciadopitys verticillata (*), I, p. 708.

Sequoia gigantea, I, p. 707 .

S. sempervirens (*), I, p. 706.

Stangeria sp. (*), III, p. 442.

Taxaceae $(*)$, I, p. 690.

Taxus baccata (*), I, p. 692.

T. cuspidata, I, p. 693 .

Thuja japonica, I, p. 703 .

$T$. orientalis, I, p. 7०3.

T. orientalis var. aurea, I, p. 703 .

T. sphaeroidea, I. p. $7 \circ 3$.

Tsuga canadensis, II, p. I90.

$T$. diversifolia, II, p. I9I.

Torreya Myristica, I, p. 693.

Welwitschia mirabilis (*), IV, p. 322.

Widdringtonia Mahoni, I, p. 706.

W. Whytei, I, p. 706.

Zamia, III, p. 454. 


\section{$2 \mathrm{BHL}$ Biodiversity Heritage Library}

Hill, T. G. and De Fraine, E. 1910. "On the seeding structure of Gymnosperms. IV." Annals of botany 24, 319-333.

https://doi.org/10.1093/oxfordjournals.aob.a089269.

View This Item Online: https://www.biodiversitylibrary.org/item/262605

DOI: https://doi.org/10.1093/oxfordjournals.aob.a089269

Permalink: https://www.biodiversitylibrary.org/partpdf/319777.

\section{Holding Institution}

New York Botanical Garden, LuEsther T. Mertz Library

\section{Sponsored by}

BHL-SIL-FEDLINK

\section{Copyright \& Reuse}

Copyright Status: Public domain. The BHL considers that this work is no longer under copyright protection.

This document was created from content at the Biodiversity Heritage Library, the world's largest open access digital library for biodiversity literature and archives. Visit BHL at https://www.biodiversitylibrary.org. 